\title{
Characterization of Total Phenol and Flavonoid Contents, Colour, Functional Properties from Honey Samples with Different Floral Origins
}

\author{
Alma Delia Hernández-Fuentes ${ }^{\mathrm{a}}$, David Chávez-Borges ${ }^{\mathrm{a}}$, Antonio de Jesús \\ Cenobio-Galindo ${ }^{a}$, Andrea Paloma Zepeda-Velázquez ${ }^{a}$, Ana Cristina Figueira ${ }^{\text {b }}$, \\ RubÉn Jiménez-Alvarado ${ }^{a}$, And Rafael Germán CAmpos-Montiel ${ }^{{ }^{*}}$ \\ ${ }^{a}$ Instituto de Ciencias Agropecuarias, Universidad Autónoma del Estado de Hidalgo. Av. Rancho \\ Universitario s/n Km. 1. C.P. 43600, Tulancingo, Hidalgo, México \\ b Research Centre for Tourism, Sustainability and Well-being (CinTurs) and Department of Food Engineering, \\ Institute of Engineering, University of the Algarve, Campus da Penha, 8005-139 Faro, Portugal \\ ${ }^{*}$ Corresponding author \\ ragcamposm@gmail.com \\ TEL: (52)7717172000
}

Received: 11 May 2020; Published online: 18 October 2021

Check for updates

\begin{abstract}
Honey has long been used as a food and has been reported to have potential health benefits. In this work, total phenol content, colour and antioxidant and hepatoprotective activities of honey samples of different floral origins from the State of Hidalgo, Mexico were explored using in vitro assays. Hepatoprotective activity was measured by inhibitition of $\beta$-glucuronidase; gastroprotective activity was determined by inhibition of urease; antioxidant activity was evaluated by 2,2 '-Azino-bis-3ethylbenzothiazoline-6-sulfonic acid (ABTS) and 2, 2-diphenyl-1-picrylhydrazyl (DPPH) methods. All the parameters showed significant differences $(\mathrm{p}<0.05)$ among honey samples. The total phenolic content ranged from 18.02 to $102.77 \mathrm{mg} \mathrm{GAE} 100 \mathrm{~g}^{-1}$. The colour ranged from extra light amber to dark amber. Inhibition of $\beta$-glucuronidase ranged from $23.70 \%$ to $36.00 \%$, while urease inhibition ranged between $7.64 \%$ and $63.80 \%$. The antioxidant activity by ABTS was between 44.68 and $441.56 \mathrm{mg}$ AAE $100 \mathrm{~g}^{-1}$, and DPPH showed activities ranging from 35.64 to $573.06 \mathrm{mg}$ AAE $100 \mathrm{~g}^{-1}$. All honey samples contained bioactive compounds and displayed functional properties; therefore, the honeys from this region of Mexico offer attractive characteristics for their potential use in the food industry.
\end{abstract}

Keywords: Phenols; Flavonoids; Colour; $\beta$-glucuronidase; Urease

\section{Introduction}

Honey is a natural substance produced by honeybees, of the species Apis mellifera, from the nectar of flowers and plant secretions. This natural product has several food and clinical applications and contains approximately 200 different chemical components, including fructose, glucose, water, proteins, amino acids, enzymes, vit- amins and minerals (Alvarez-Suarez et al., 2010; Rao et al., 2016). Honey is an important food product since it contains bioactive compounds derived from plants and the bees that produce it: honey is rich in phenolic acids and flavonoids, which have a wide range of biological functions and act as natural antioxidants (Kaskoniene et al., 2009). The colour of honey is one of its most distinctive characteristics, and is used as an in- 
dication of the presence of phenolic compounds and their derivatives and their potential antioxidant activities (Estevinho et al., 2008).

There are several reports that suggest that the composition and antioxidant capacity of different honeys depend mainly on the floral origin of the nectar collected by bees, other environmental factors and even processing. These factors demonstrate that there is a correlation between the origin and the identified components of the honey (Baharudin et al., 2017; Marghitas et al., 2009; Pimentel-Gonzalez et al., 2016). Recent research indicates that the main factor that gives diversity of colour, flavour and functional properties to honey is its phenolic composition (Hossen et al., 2017). These compounds demonstrate biological activity that have beneficial effects on health (Bueno-Costa et al., 2016; Estevinho et al., 2008). Phenolic compounds and flavonoids can give insight into the botanical origin of honey; therefore, the phenolic composition and antioxidant capacity of honey depend on the floral sources used to obtain this honey, as well as seasonal and environmental factors (Yao et al., 2003).

Current trends show that there are studies using natural compounds aimed at tumour and cancer inhibition; to reduce the need for chemical therapies and surgical interventions (Khan et al., 2017). Polyphenols in honey can chemically prevent different stages of cancer, including tumour formation and growth, through the inactivation of carcinogenic compounds, cell cycle arrest, apoptosis induction, the reduction of angiogenesis and antioxidation (Fresco et al., 2006).

An important function of the bioactive compounds found in honey is prevention of loss of biological membranes and enzymes functionality by elimination of free radicals that would otherwise induce the oxidation of lipids, proteins and DNA, in living systems (Mouhoubi-Tafinine et al., 2016; Niki, 2011). Various plant species have been studied for their capacity to inhibit certain enzymes to confer health benefits. The hepatoprotective effect is attributed to the inhibition of the $\beta$-glucuronidase enzyme (Karak et al., 2017), and gastroprotective activity is related to urease inhibition (Biglar et al., 2012). This study was conducted on honey samples with different floral origins by measuring the total phenol and flavon- oid contents, the colour, and the functional properties such as hepatoprotective, gastroprotective and antioxidant activities.

\section{Materials and Methods}

\subsection{Honey samples}

A total of 24 samples of honey from different regions of the state of Hidalgo, Mexico were obtained directly from beekeepers and evaluated. The samples were collected in the period MarchApril 2018 from 24 different sites (Table 1). The collection was carried out at room temperature $\left(20-25{ }^{\circ} \mathrm{C}\right)$ and the samples were later taken to the Institute of Agricultural Sciences of the Autonomous University of Hidalgo State in closed, dark containers. The honey samples were coded and stored in the dark at room temperature until they were analysed. The floral origin of the honey samples was determined according to the methodology developed by Sodre et al. (2007). For a quantitative analysis of pollen, 300 pollen grains were used for each sample in triplicate. Subsequently, visual comparisons of pollen were made using a BX 45 light microscope (Olympus, Japan).

\subsection{Total phenolic content}

The phenolic content in honey samples was determined using the Folin-Ciocalteu method (Singleton et al., 1999). Honey was diluted 1:10 with distilled water, and the resulting solution was filtered using Whatman No. 1 paper filter. The filtered solution $(5 \mathrm{~mL})$ was mixed with 2.5 $\mathrm{mL}$ of $0.2 \mathrm{~N}$ Folin-Ciocalteu phenol reagent for 5 minutes, and then $2 \mathrm{~mL}$ of $\mathrm{Na}_{2} \mathrm{CO}_{3}$ solution $(75$ $\mathrm{g} \mathrm{L}^{-1}$ ) was added. Samples were left to stand for $2 \mathrm{~h}$ at room temperature in the dark. After this time, the absorbance was read at $760 \mathrm{~nm}$ in a Hitachi U-2000 UV/VIS spectrophotometer (Tokyo, Japan), using water as a blank. A standard curve was prepared with gallic acid in solutions of different concentrations (0-100 mg of gallic acid $\left.100 \mathrm{~g}^{-1}\right)$; therefore, results of the phenolic content in honey samples were expressed as $\mathrm{mg}$ of gallic acid equivalents (GAE) $100 \mathrm{~g}^{-1}$ of honey. 
Table 1: Main characteristics of Mexican honey samples

\begin{tabular}{lcc}
\hline Honey & Collection site & Floral origin \\
\hline $1 \mathrm{SA}$ & San Andrés & Cactus \\
$2 \mathrm{SF}$ & San Felipe Orizatlán & Cítrus \\
$3 \mathrm{AC}$ & Acaxochitlán & Gramineae \\
$4 \mathrm{ER}$ & El Real & Conífers \\
$5 \mathrm{AT}$ & Atotonilco & Juglans \\
$6 \mathrm{HU}$ & Huejutla & Cítrus \\
$7 \mathrm{TE}$ & Tehuetlán & Multifloral \\
$8 \mathrm{HU}$ & Huautla & Multifloral \\
$9 \mathrm{AM}$ & Tenango de Doria & Multifloral \\
$10 \mathrm{NR}$ & Tepeji del Rio & Multifloral \\
$11 \mathrm{WR}$ & Acatlán & Multifloral \\
$12 \mathrm{VZ}$ & Zimapán & Multifloral \\
$13 \mathrm{ML}$ & San Felipe Orizatlán & Cítrus \\
$14 \mathrm{AB}$ & San Bartolo Tutotepec & Multifloral \\
$15 \mathrm{OS}$ & Huejutla & Cítrus \\
$16 \mathrm{FA}$ & Zimapán & Multifloral \\
$17 \mathrm{JG}$ & Almoloya & Multifloral \\
$18 \mathrm{HA}$ & Texcoco & Multifloral \\
$19 \mathrm{JJ}$ & Almoloya & Multifloral \\
$20 \mathrm{ME}$ & Tepeapulco & Multifloral \\
$21 \mathrm{MA}$ & Apan & Multifloral \\
$22 \mathrm{VM}$ & Apan & Multifloral \\
$23 \mathrm{OR}$ & Zimapán & Multifloral \\
$24 \mathrm{MJ}$ & Tlanalapa & Multifloral \\
\hline
\end{tabular}

\subsection{Flavonoid content}

The total flavonoid content was measured using the Dowd method as reported by Meda et al. (2005). Approximately $1 \mathrm{~g}$ of each honey sample was mixed with $10 \mathrm{~mL}$ of pure methanol, and the solution was stirred and then centrifuged at $15,000 \mathrm{rpm}$ for 15 minutes. Then, $2 \mathrm{~mL}$ of the suspended liquid was mixed with $2 \mathrm{~mL}$ of $2 \%$ aluminium trichloride $\left(\mathrm{AlCl}_{3}\right)$ and left to stand in the dark for 20 minutes. The absorbance was measured at $415 \mathrm{~nm}$ in a UV/VIS spectrophotometer (Hitachi U-2000, Tokyo, Japan). A standard curve was prepared of quercetin in different concentrations (0-100 mg of quercetin $\left.100 \mathrm{~g}^{-1}\right)$; therefore, the flavonoid content was expressed in $\mathrm{mg}$ of quercetin equivalents (EQ) $100 \mathrm{~g}^{-1}$ of honey.

\subsection{Colour determination using the Pfund scale}

Honey colour was determined by reading the absorbance of a $50 \%$ honey solution in water $(\mathrm{w} / \mathrm{v})$ read at $635 \mathrm{~nm}$ in a $1 \mathrm{~mL}$ cell, in a UV/VIS spectrophotometer (Hitachi U-2000) following the method previously reported by Ferreira et al. (2009). The honey samples were classified, after obtaining the readings, using the Pfund scale by converting the absorbance values, applying equation 1 and comparing the results with the honey colour chart.

$m m P$ fund $=-38.70+(371.39 \times$ absorbance $)$ 


\subsection{Antioxidant Activity}

\section{2,2'-azino-bis-3-ethylbenzothiazoline- 6-sulfonic acid (ABTS)}

The antioxidant activity was determined by the discolouration of the ABTS radical (SigmaAldrich, Canada), as described by Re et al. (1999): $\quad 7 \mu \mathrm{M}$ ABTS radical was reacted with $2.45 \mu \mathrm{M}$ potassium persulfate $\left(\mathrm{K}_{2} \mathrm{~S}_{2} \mathrm{O}_{8}\right)$ (Mallinckrodt Chemicals, USA) in a 1:1 ratio and stirred for 16 hours in the dark. When the radical was formed, it was diluted with ethanol (20\%) until reaching an absorbance of $0.7 \pm 0.01$ at 734 $\mathrm{nm}$. Once the radical was stabilized, $3 \mathrm{~mL}$ of this solution was placed in a test tube, and 100 $\mu \mathrm{L}$ of honey extract was added. The mixture was stirred rapidly, and the absorbance was measured after 10 minutes of reaction. The absorbance of the ethanol (20\%)-diluted solution was used as the blank. A standard curve was prepared with ascorbic acid at different concentrations $(0-100$ $\mathrm{mg}$ of ascorbic acid $100 \mathrm{~g}^{-1}$ ); therefore, the results were expressed in milligrams of ascorbic acid equivalents (AAE) $100 \mathrm{~g}^{-1}$ of honey.

\section{2,2-diphenyl-1-picrylhydrazyl (DPPH)}

To prepare the $0.2 \mathrm{mM}$ DPPH solution, 7.8 $\mathrm{mg}$ of DPPH radical (Sigma-Aldrich, USA) was weighed and dissolved in $100 \mathrm{~mL}$ of methanol $(80 \%)$, and the mixture was stirred in the dark for two hours for complete dissolution. Then, 2.5 $\mathrm{mL}$ of methanolic DPPH solution was added to a test tube, reacted with $0.5 \mathrm{~mL}$ of honey solution, and the mixture was left in the dark for 30 minutes and read at an absorbance of $515 \mathrm{~nm}$. The antioxidant activity was determined using a standard curve with ascorbic acid. The results were expressed in milligrams AAE $100 \mathrm{~g}-1$ of honey (Brand-williams et al., 1995).

\section{$2.6 \beta$-Glucuronidase inhibition}

This analysis was carried out following the methodology described by Karak et al. (2017) with a few modifications. A dilution of the honey with water was made at $10 \%$, from which 340 $\mu \mathrm{L}$ was taken and mixed with $100 \mu \mathrm{L}$ of a $\beta$ glucuronidase solution (986.4 units $\mathrm{mL}^{-1}$ in $\mathrm{pH}$ 7 phosphate buffer) (Sigma-Aldrich, USA), and the mixture was pre-incubated at $37{ }^{\circ} \mathrm{C}$ for 15 minutes. Subsequently, $60 \mu \mathrm{L}$ of p-nitrophenyl$\beta$-D-glucuronide $\left(3.15 \mathrm{mg} \mathrm{mL}^{-1}\right.$ in $\mathrm{pH} 7$ phosphate buffer) (Sigma-Aldrich, USA) was added and incubated for 50 minutes at $37^{\circ} \mathrm{C}$. The absorbance was measured at $405 \mathrm{~nm}$ in a spectrophotometer. A control test was carried out with D-saccharic acid 1,4-lactone following the same steps as analysis of honey samples, and the percentage inhibition was obtained using equation 2:

$\%$ Inhibition $=\left[\frac{\text { absorbance of Control }- \text { absorbance of Sample }}{\text { absorbance of Control }}\right] \times 100$

\subsection{Urease inhibition}

The urease inhibition test was performed as described by Biglar et al. (2012) with a few modifications. For each honey sample, $100 \mu \mathrm{L}$ of urease solution (Jack bean urease $5 \mathrm{U} \mathrm{mL}^{-1}$ ) and $100 \mu \mathrm{L}$ of inhibitor (a $20 \%$ dilution of honey in a $50 \%$ ethanol-water solution) were mixed and incubated at $37^{\circ} \mathrm{C}$ for 10 minutes. Then, a solution of urea prepared in phosphate buffer $(\mathrm{pH}$ 6.8) was added and incubated at $37^{\circ} \mathrm{C}$ for 30 minutes. The urease activity was determined by measuring the production of ammonia using the indophenol method. The reaction was stopped with $600 \mu \mathrm{L}$ of $4 \%$ sulfuric acid. Subsequently, $100 \mu \mathrm{L}$ of solution A ( $5.0 \mathrm{~g}$ phenol and $25 \mathrm{mg}$ of sodium nitroprusside) and $100 \mu \mathrm{L}$ of solution $\mathrm{B}$ ( $2.5 \mathrm{~g}$ sodium hydroxide and $4.2 \mathrm{~mL}$ of sodium hypochlorite in $500 \mathrm{~mL}$ of distilled water) were added, the samples were left in darkness for 30 minutes at $37^{\circ} \mathrm{C}$, and the absorbance was measured at $625 \mathrm{~nm}$.

\subsection{Statistical analysis}

For the statistical analysis, a completely randomized design was used. The results were interpreted with analysis of variance, and when significant differences were observed $(\mathrm{p}<0.05)$ between the different honeys, the mean comparison was performed by the Tukey method using the NCSS 2007 software (USA). 
Table 2: Bioactive compounds and honey color

\begin{tabular}{|c|c|c|c|c|}
\hline Honey & Total phenols & Flavonoids & Pfund Scale (mm) & Color \\
\hline $1 \mathrm{SA}$ & $25.65 \pm 0.0 .49^{c}$ & $3.95 \pm 0.20^{i j k}$ & 105.3 & Amber \\
\hline $2 \mathrm{SF}$ & $18.02 \pm 0.49^{a}$ & $4.97 \pm 0.52^{l}$ & 71.8 & Light amber \\
\hline $3 \mathrm{AC}$ & $92.32 \pm 1.29^{\circ}$ & $7.63 \pm 0.51^{n}$ & 93.6 & Amber \\
\hline $4 \mathrm{ER}$ & $93.16 \pm 0.98^{\circ}$ & $7.01 \pm 0.52^{m n}$ & 135.8 & Dark amber \\
\hline $5 \mathrm{AT}$ & $102.49 \pm 0.98^{p}$ & $1.28 \pm 0.26^{a}$ & 88.7 & Amber \\
\hline $6 \mathrm{HU}$ & $93.73 \pm 0.85^{\circ}$ & $2.02 \pm 0.34^{a b c}$ & 69.2 & Light amber \\
\hline $7 \mathrm{TE}$ & $102.77 \pm 1.29^{p}$ & $3.49 \pm 0.52^{g h i j}$ & 138.1 & Dark amber \\
\hline $8 \mathrm{HU}$ & $51.10 \pm 0.49^{k}$ & $1.79 \pm 0.20^{a b}$ & 65.9 & Light amber \\
\hline $9 \mathrm{AM}$ & $43.10 \pm 0.97^{i j}$ & $2.25 \pm 0.10^{b c d}$ & 42.9 & Extra light amber \\
\hline $10 \mathrm{NR}$ & $49.44 \pm 0.33^{k}$ & $6.33 \pm 0.07^{m}$ & 110.7 & Amber \\
\hline $11 \mathrm{WR}$ & $38.46 \pm 0.33^{f g}$ & $2.37 \pm 0.14^{b c d e}$ & 59.6 & Light amber \\
\hline $12 \mathrm{VZ}$ & $72.95 \pm 0.72^{n}$ & $5.42 \pm 0.16^{l}$ & 125.6 & Dark amber \\
\hline $13 \mathrm{ML}$ & $57.30 \pm 0.41^{l}$ & $2.77 \pm 0.07^{c d e f g}$ & 26.2 & White \\
\hline $14 \mathrm{AB}$ & $44.26 \pm 0.23^{j}$ & $3.24 \pm 0.23^{f g h i}$ & 81.8 & Light amber \\
\hline $15 \mathrm{OS}$ & $64.08 \pm 0.23^{m}$ & $5.37 \pm 0.09^{l}$ & 64.7 & Light amber \\
\hline $16 \mathrm{FA}$ & $71.58 \pm 0.22^{n}$ & $3.56 \pm 0.21^{h i j}$ & 242.3 & Dark amber \\
\hline $17 \mathrm{JG}$ & $35.65 \pm 0.38^{e}$ & $3.19 \pm 0.07^{e f g h}$ & 140.7 & Dark amber \\
\hline $18 \mathrm{HA}$ & $22.34 \pm 0.54^{b}$ & $2.11 \pm 0.05^{a b c}$ & 40.3 & Extra light amber \\
\hline 19JJ & $33.02 \pm 0.62^{d}$ & $3.04 \pm 0.09^{\text {defgh }}$ & 233.2 & Dark amber \\
\hline $20 \mathrm{ME}$ & $41.10 \pm 0.17^{h i}$ & $4.51 \pm 0.05^{k l}$ & 122.6 & Dark amber \\
\hline $21 \mathrm{MA}$ & $36.68 \pm 0.711^{e f}$ & $2.94 \pm 0.07^{\text {cdefgh }}$ & 111.5 & Amber \\
\hline $22 \mathrm{VM}$ & $24.33 \pm 0.17^{b c}$ & $2.30 \pm 0.04^{b c d}$ & 86.1 & Amber \\
\hline $23 \mathrm{OR}$ & $39.15 \pm 0.35^{g h}$ & $4.35 \pm 0.07^{j k}$ & 175.1 & Dark amber \\
\hline $24 \mathrm{MJ}$ & $41.50 \pm 0.49^{i}$ & $2.44 \pm 0.29^{b c d e f}$ & 100.2 & Amber \\
\hline
\end{tabular}

The results are expressed in means \pm standard deviation. Different letters indicate statistically significant differences between the analyzed samples $(\mathrm{p}<0.05)$. Total phenols are expressed in mg GAE $100 \mathrm{~g}^{-1}$. Flavonoids are expressed in mg QE 100 $\mathrm{g}^{-1}$.

\section{Results and Discussion}

\subsection{Total phenolic content}

Significant differences $(\mathrm{p}<0.05)$ were found between the different honey samples. The samples with the highest phenolic contents were 5AT and 7TE (of Juglan and multifloral origin, respectively), of $102.49 \pm 0.98$ and $102.77 \pm 1.29$ mg EAG $100 \mathrm{~g}^{-1}$, respectively (Table 2). Various analyses of the total phenolic content in different honey samples have been carried out worldwide. Our results are similar to those reported by RuizNavajas et al. (2011) who found values ranging between 51.32 and $134.02 \mathrm{mg}$ EAG $100 \mathrm{~g}^{-1}$ in honey from south eastern Mexico with warm and tropical climates. The difference in the content of total phenols among the samples analysed is due to the diverse geographical origin, quality and the floral source from which they were extracted (Al-Farsi et al., 2018).

\subsection{Flavonoid content}

The results for flavonoid revealed that the honey samples with the highest content were $3 \mathrm{AC}$ and 4ER both with more than $7 \mathrm{mg}$ EQ $100 \mathrm{~g}^{-1}$ (of Gramineae and Conifers origin, respectively). It should be mentioned that none of the samples had values less than $1 \mathrm{mg}$ EQ $100 \mathrm{~g}^{-1}$ or more 
than $10 \mathrm{mg}$ EQ $100 \mathrm{~g}^{-1}$. The results obtained in this study are comparable to those presented by Meda et al. (2005) in Burkina Faso honey samples with an average flavonoid content of $2.57 \mathrm{EQ} 100 \mathrm{~g}^{-1}$, similar to the samples with the lowest content in this study. A study conducted in Brazil by Bueno-Costa et al. (2016) in which they also determined flavonoid content obtained a range of results between 2.98 and $10.46 \mathrm{mg}$ EQ $100 \mathrm{~g}^{-1}$, very similar to the results presented here; however, the upper concentration limit in this Brazilian honey was slightly higher than that obtained in our samples. Unlike the studies mentioned above, Boussaid et al. (2018) reported very low content compared to the other results. Flavonoids are phenolic compounds and are present as various types of structures in honey; among them, the one with the highest content according to Alvarez-Suarez et al. (2012) is quercetin, while Quintero-Lira et al. (2017) reported the major flavonoid was rutin. The concentrations of these compounds are determined by the botanical and geographical origins of the samples, as well as the climate and environmental conditions such as humidity, temperature and type of soil where the plants grew (Al-Farsi et al., 2018). Flavonoid content and pigments derived from these compounds are also directly related to the colour of honey and its different shades (Alvarez-Suarez et al., 2010). Also, phenolic compounds and flavonoids can be used as an indicator of antioxidant activity since they have sequestering and free radical reduction capacity (da Silva et al., 2016).

\subsection{Colour evaluation}

The results showed that the darkest honey samples classified as "dark amber" were $4 \mathrm{ER}$, 7TE, 12VZ, 17JE, 19JJ, 20ME, 23OR and 16FA (mainly of Conifers and Multifloral origin), with the highest level on the scale reaching $242.3 \mathrm{~mm}$. Most samples had dark tones and fell under the "amber" classification or higher (Table 2). Compared to the results of honey colour in other studies, the honey colour in the samples analysed here showed large variations, with very high to low values on the Pfund scale that depended on when the colour analysis was performed. An ana- lysis performed in Brazil by Pontis et al. (2014) identified honey samples classified as very clear "extra light amber"; however, the study also had samples within the "dark amber" range but with values lower than those found in our samples. Many authors agree that honey colour is directly related to the presence of phenolic compounds and their antioxidant capacity (Bertoncelj et al., 2007; Ferreira et al., 2009) due to the high correlation values in the tests performed. Therefore, the colour, smell and taste of honey are related to the phenolic content and are indicators and characteristics of floral origin (Bertoncelj et al., 2007; Kaskoniene et al., 2009).

\subsection{Antioxidant activity}

The antioxidant activity in the honey samples was determined by the ABTS and DPPH methods, obtaining results in equivalent milligrams of ascorbic acid (Figure 1). In both cases, significant differences $(p<0.05)$ were found between the analysed samples. In the ABTS test, the highest content were found in the following honey sample: 13ML (405.10 $\pm 30.83 \mathrm{mg}$ EAA $\left.100 \mathrm{~g}^{-1}\right)$ of a citrus floral origin, and 24MJ (410.31 \pm 3.12 mg EAA $100 \mathrm{~g}^{-1}$ ) and 17JG (441.56 $\pm 6.25 \mathrm{mg}$ EAA $100 \mathrm{~g}^{-1}$ ), both of multifloral origin.

In DPPH test the highest content were found in the $12 \mathrm{VZ}$ honey sample, of multifloral origin $\left(573.06 \pm 10.20 \mathrm{mg}\right.$ EAA $\left.100 \mathrm{~g}^{-1}\right)$, showing significant differences with respect to the rest of the honey samples. Several studies have presented information on the antioxidant activity of honey. El-haskoury et al. (2018) performed tests on honey from Morocco and found average results of $60.94 \mathrm{mg}$ EAA $100 \mathrm{~g}^{-1}$, which is lower than the results obtained in this study; however, they obtained superior antioxidant activity in the ABTS test in relation to DPPH. A Portuguese honey was analysed by Ferreira et al. (2009) using DPPH test, and reported values between 106.67 and $168.94 \mathrm{mg}$ EAA $100 \mathrm{~g}^{-1}$ with few samples being characterised as light honey and more as dark honey; a similar trend was also found in a study reported by Estevinho et al. (2008) with similar samples from Portugal. The results of antioxidant activity are directly related to the total phenol content in honey, as determ- 


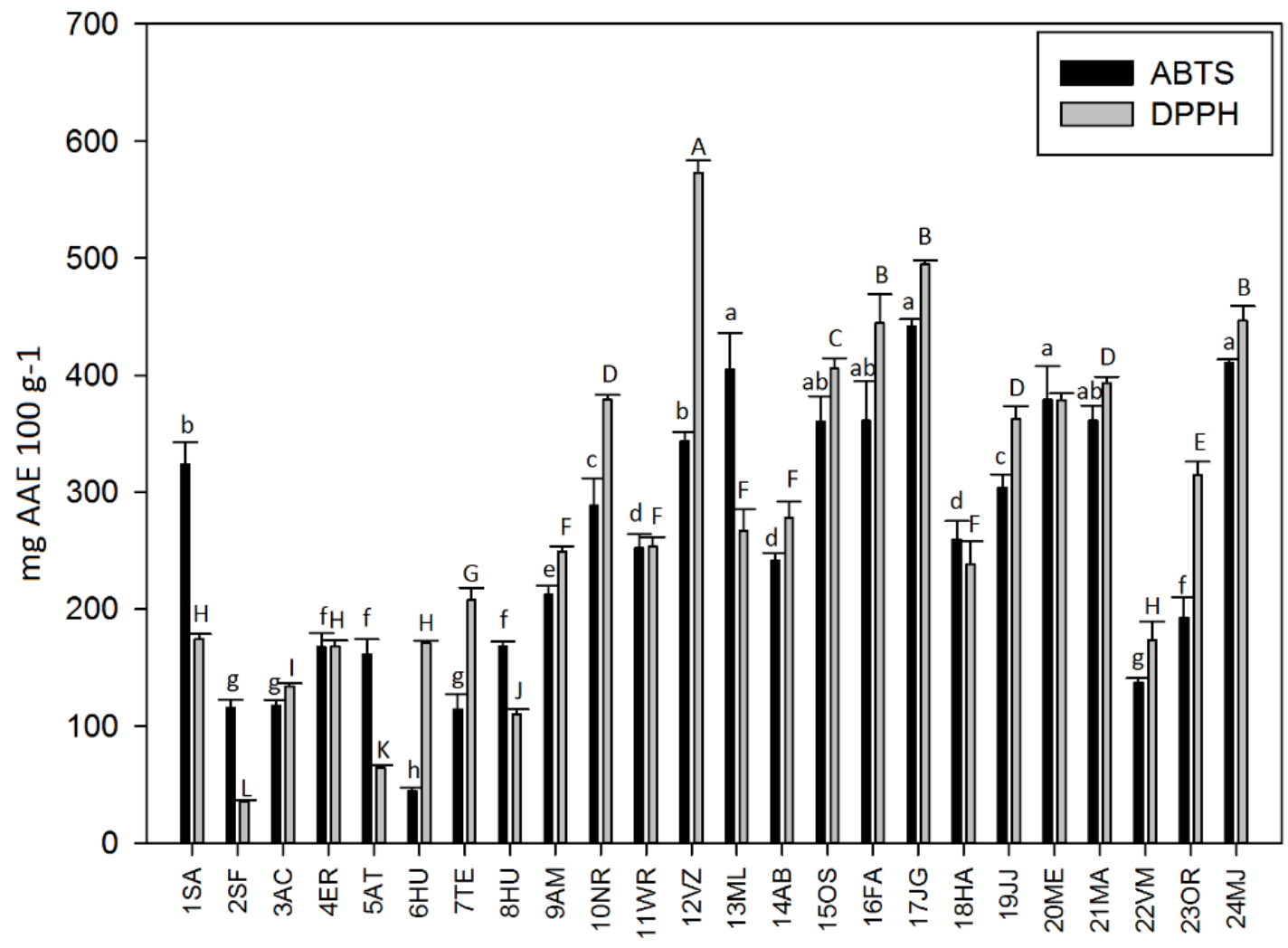

Figure 1: Antioxidant activity of Mexican honeys. The results are expressed in means \pm standard deviation. Lowercase letters indicate differences between treatments for the ABTS test $(\mathrm{p}<0.05)$. Capital letters indicate differences between treatments for the DPPH test $(\mathrm{p}<0.05)$.

ined by Bertoncelj et al. (2007), who found high correlation factors between both tests, as with the colour intensity.

Based on the determination of the ABTS and DPPH tests performed by Bueno-Costa et al. (2016), it was found that the most appropriate test for antioxidant determination is ABTS since it shows high correlations with the content of phytochemical analytes such as phenols, flavonoids, phenolic acids and carotenoids. The literature mentions that the mechanisms of antioxidant activity in honey include the ability to sequester free radicals, the chelation of metal ions and the oxidizing-reducing capacity of phenolic compounds due to the presence of hydroxyl groups attached to aromatic rings (Bastos \& Sampaio, 2013). It is also known that the antioxidant capacity and the colour of honey are affected by the floral source, differences in geographical origin, humidity, soil type and post-harvest conditions (Al-Farsi et al., 2018).

\section{$3.5 \beta$-Glucuronidase inhibition}

The results shown in figure 2 were obtained from the $\beta$-glucuronidase inhibition test. All the honey samples have positive inhibition values higher than $20 \%$. The following samples had the highest percentages: $8 \mathrm{HU}(33.21 \pm 1.96 \%), 1 \mathrm{SA}$ $(33.64 \pm 1.83 \%)$ and $2 \mathrm{SF}(36.00 \pm 0.47 \%)$ (mainly 


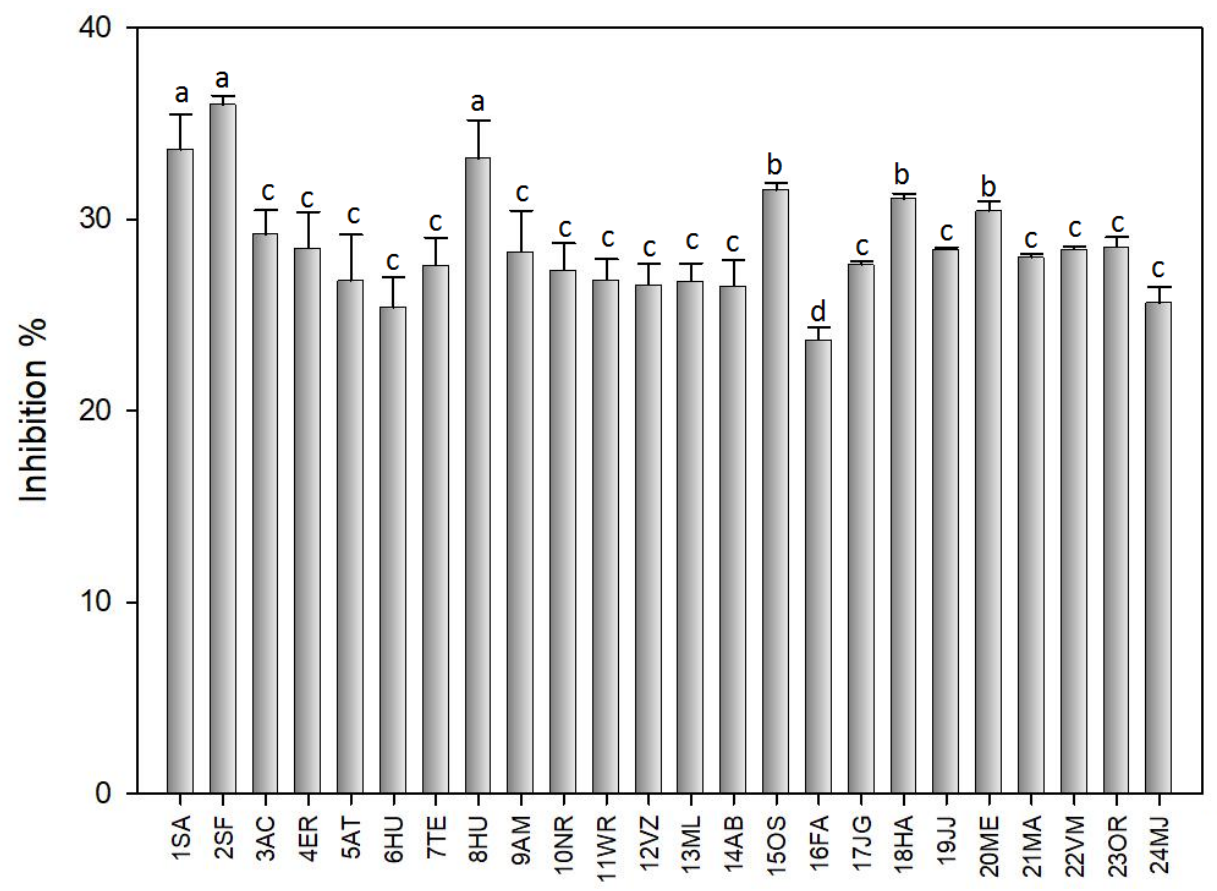

Figure 2: Inhibition percent of $\beta$-glucuronidase in Mexican honeys. The results are expressed in means \pm standard deviation. Different letters indicate differences between treatments $(\mathrm{p}<0.05)$.

of cactus, citrus and multifloral origin). The results are similar between different samples that range between $25 \%$ and $30 \%$, with some honey samples exhibiting higher peaks. The analyses that have been performed on the inhibition of $\beta$ glucuronidase by bioactive compounds are limited. Han et al. (2005) evaluated the hepatoprotective effect of lactic acid bacteria with an inhibition range of $17 \%$ to $66 \%$ in an in vivo study with rats. Swertia sp. plant extracts have been studied as a $\beta$-glucuronidase inhibitor; Karak et al. (2017) found an average inhibition percentage of $30.89 \%$ from a concentration of $500 \mu \mathrm{g} \mathrm{mL}-1$ of the $S$. bimaculate.

$\beta$-Glucuronidase is used as a marker of various diseases because it is a member of the lysosomal glucosidase family, which catalyses the degradation of glycosaminoglycans of normal and cancerous tissue cell membranes (Baharudin et al., 2017). Glucuronic acid conjugates with toxins and diminishes their potency by eliminating them from the body later; this process is limited by high levels of $\beta$-glucuronidase (Karak et al.,
2017). Liver damage causes an increase in the level of $\beta$-glucuronidase in the blood, and liver cancer may be related to this enzyme. Inhibitors of this indicator reduce the carcinogenic potential of toxic compounds. Therefore, inhibitors of $\beta$-glucuronidase are suggested as potential hepatoprotective agents (Shim et al., 2000). Some extracts and compounds from plants with hepatoprotective activities are known for their ability to inhibit this type of enzyme, among which are flavonoids (Joshi \& Priya, 2007; Kim et al., 1994).

\subsection{Urease inhibition}

All honey samples exhibited urease inhibition, exceeding 20\% in most samples (Figure 3). A clear variation was seen among the samples analysed, showing significant differences $(\mathrm{p}<0.05)$. Sample 10NR $(63.80 \pm 0.11 \%)$ had the greatest inhibition (of multifloral origin), followed by $15 \mathrm{OS}$ $(58.73 \pm 0.62 \%)$ and $4 \mathrm{ER}(59.24 \pm 3.64 \%)$. Cur- 


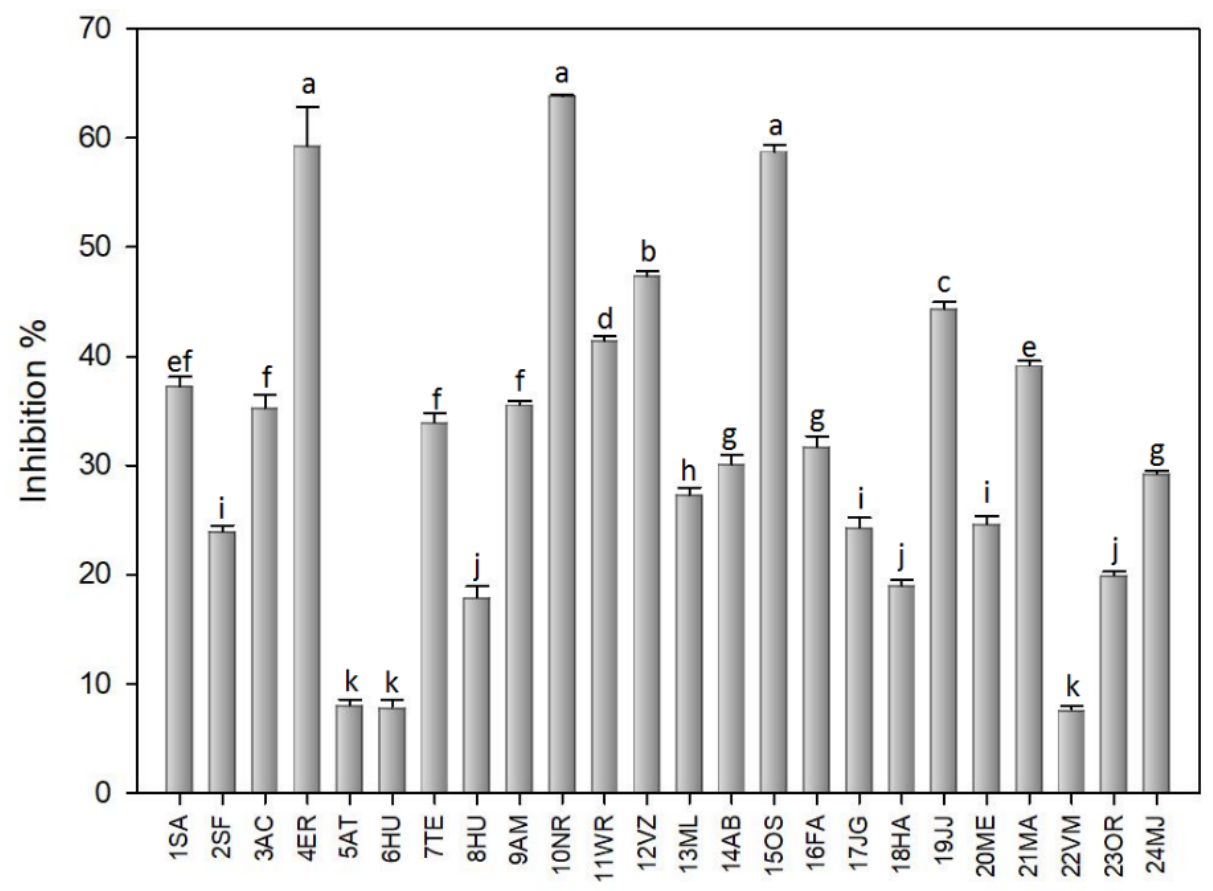

Figure 3: Inhibition percent of urease in Mexican honeys. The results are expressed in means \pm standard deviation. Different letters indicate differences between treatments $(\mathrm{p}<0.05)$.

rent research on urease inhibition is focused on gastric protection and ulcer reduction; however, most studies are based on plant extracts and isolates. On the one hand, Lateef et al. (2012) analysed Glycyrrhiza glabra roots and found an approximate average urease inhibition value of $61 \%$ with a methanolic extraction and $40 \%$ in an extraction with chloroform. These results are within the range of those found in honey. On the other hand, Lin et al. (2005) evaluated the enzymatic inhibition of urease in oregano, and found an approximate value of $40 \%$, which also coincides with results observed here. In the same study, the activity of cranberry was also evaluated, resulting in $9 \%$ inhibition.

The study on the inhibition of urease is aimed at determining the presence of Helicobacter pylori since this gram-positive bacterium causes chronic gastritis and intervenes directly in the formation of peptic ulcers, carcinoma and gastric lymphoma (Dunn et al., 1997). The gastric mucosa is affected by $H$. pylori since it resists the acidic environment producing urease, which hydrolyses urea-forming bicarbonate and ammonium ( $\mathrm{Hu} \&$ Mobley, 1990; Kuhns et al., 2013). The methanolic extracts of vegetable sources can be considered a natural source for the inhibition of urease, as mentioned by Lateef et al. (2012), so it is possible that these compounds can be transferred to honey, generating a similar effect. The difference in the enzymatic inhibitory activity is mainly due to the type of phenolic compounds in the inhibitor, as verified by Lin et al. (2005), who demonstrated that hydrophobic phenolic compounds such as those present in oregano are superior in urease inhibition than those that are soluble in water, such as those found in blueberries. In honey, phenolic derivatives such as flavonoids behave both ways since they are liposoluble and water soluble (MartínezFlórez et al., 2002), this is reflected in the varied behaviour of urease inhibition. 


\section{Conclusion}

The honey samples analysed in this study were a good source of phenolic compounds, especially the honey of walnut and multifloral origin, and had good antioxidant activity, as in the case of honeys $17 \mathrm{JG}$ and $12 \mathrm{VZ}$ (multiflorals). $\beta$-glucuronidase inhibition values indicated the presence of possible hepatoprotective activity, and some honey samples showed high values of possible gastric protective activity as exhibited by the urease inhibition test in vitro. Differences between the honey samples in each test demonstrated that the characteristics of each honey sample were unique, probably due to the compounds they contain derived from different plant origins. This study provides an insight to potential area of opportunity for future research related to the possible beneficial effects of honeys in the region studied, which the native population uses even in traditional medicine.

\section{Acknowledgements}

This paper is partially financed by National Funds provided by FCT- Foundation for Science and Technology throughout project UID/SOC/04020/2020.

\section{References}

Alvarez-Suarez, J. M., Giampieri, F., GonzálezParamás, A. M., Damiani, E., Astolfi, P., Martinez-Sanchez, G., Bompadre, S., Quiles, J. L., Santos-Buelga, C. \& Battino, M. (2012). Phenolics from monofloral honeys protect human erythrocyte membranes against oxidative damage. Food and Chemical Toxicology, 50(5), 1508-1516.

Alvarez-Suarez, J. M., Tulipani, S., Diaz, D., Estevez, Y., Romandini, S., Giampieri, F., Damiani, E., Astolfi, P., Bompadre, S. \& Battino, M. (2010). Antioxidant and antimicrobial capacity of several monofloral cuban honeys and their correlation with color, polyphenol content and other chemical compounds. Food and Chemical
Toxicology, 48(8-9), 2490-2499. https:// doi.org/10.1016/j.fct.2010.06.021

Baharudin, M. S., Taha, M., Imran, S., Ismail, N. H., Rahim, F., Javid, M. T., Khan, K. M. \& Ali, M. (2017). Synthesis of indole analogs as potent beta-glucuronidase inhibitors. Bioorganic chemistry, 72, 323-332.

Bastos, D. H. M. \& Sampaio, G. R. Antioxidant capacity of honey: Potential health benefit. In: Bioactive food as dietary interventions for diabetes. Elsevier, 2013, pp. 609-619.

Bertoncelj, J., Dobersek, U., Jamnik, M. \& Golob, T. (2007). Evaluation of the phenolic content, antioxidant activity and colour of slovenian honey. Food Chemistry, 105(2), 822-828. https://doi.org/ 10.1016/j.foodchem.2007.01.060

Biglar, M., Soltani, K., Nabati, F., Bazl, R., Mojab, F. \& Amanlou, M. (2012). A preliminary investigation of the jack-bean urease inhibition by randomly selected traditionally used herbal medicine. Iranian Journal of Pharmaceutical Research, $11(3), 831-837$.

Boussaid, A., Chouaibi, M., Rezig, L., Hellal, R., Donsi, F., Ferrari, G. \& Hamdi, S. (2018). Physicochemical and bioactive properties of six honey samples from various floral origins from tunisia. Arabian Journal of Chemistry, 11(2), 265274. https://doi.org/10.1016/j.arabjc. 2014.08.011

Brand-williams, W., Cuvelier, M. \& Berset, C. (1995). Use of a free-radical method to evaluate antioxidant activity. $L W T$ Food Science and Technology, 28(1), 2530.

Bueno-Costa, F. M., Zambiazi, R. C., Bohmer, B. W., Chaves, F. C., da Silva, W. P., Zanusso, J. T. \& Dutra, I. (2016). Antibacterial and antioxidant activity of honeys from the state of rio grande do sul, brazil. LWT - Food Science and Technology, 65, 333-340. https:// doi . org/10.1016/j.lwt.2015.08.018

da Silva, P. M., Gauche, C., Gonzaga, L. V., Oliveira Costa, A. C. \& Fett, R. (2016). Honey: Chemical composition, stability 
and authenticity. Food Chemistry, 196, 309-323. https : / / doi org / 10.1016/j . foodchem.2015.09.051

Dunn, B. E., Cohen, H. \& Blaser, M. J. (1997). Helicobacter pylori. Clinical Microbiology Reviews, 10(4), 720-741. https:// doi.org/10.1128/CMR.10.4.720

Estevinho, L., Pereira, A. P., Moreira, L., Dias, L. G. \& Pereira, E. (2008). Antioxidant and antimicrobial effects of phenolic compounds extracts of northeast portugal honey. Food and Chemical Toxicology, 46(12), 3774-3779. https://doi. org/10.1016/j.fct.2008.09.062

Al-Farsi, M., Al-Amri, A., Al-Hadhrami, A. \& Al-Belushi, S. (2018). Color, flavonoids, phenolics and antioxidants of omani honey. Heliyon, 4 (10). https://doi.org/ 10.1016/j.heliyon.2018.e00874

Ferreira, I. C. F. R., Aires, E., Barreira, J. C. M. \& Estevinho, L. M. (2009). Antioxidant activity of portuguese honey samples: Different contributions of the entire honey and phenolic extract. Food Chemistry, 114(4), 1438-1443. https:// doi. org/10.1016/j.foodchem.2008.11.028

Fresco, P., Borges, F., Diniz, C. \& Marques, M. P. M. (2006). New insights on the anticancer properties of dietary polyphenols. Medicinal Research Reviews, 26(6), 747-766. https://doi.org/10.1002/med. 20060

Han, S.-Y., Huh, C.-S., Ahn, Y.-T., Lim, K.-S., Baek, Y.-J. \& Kim, D.-H. (2005). Hepatoprotective effect of lactic acid bacteria, inhibitors of beta-glucuronidase production against intestinal microflora. Archives of pharmacal research, 28(3), 325 .

El-haskoury, R., Al-Waili, N., Kamoun, Z., Makni, M., Al-Waili, H. \& Lyoussi, B. (2018). Antioxidant activity and protective effect of carob honey in ccl4induced kidney and liver injury. Archives of Medical Research, 49(5), 306-313. https://doi.org/10.1016/j.arcmed.2018. 09.011

Hossen, M. S., Ali, M. Y., Jahurul, M. H. A., Abdel-Daim, M. M., Gan, S. H. \& Khalil, M. I. (2017). Beneficial roles of honey polyphenols against some human degenerative diseases: A review. Pharmacological Reports, 69(6), 1194-1205. https://doi.org/10.1016/j.pharep. 2017. 07.002

Hu, L. T. \& Mobley, H. L. T. (1990). Purification and n-terminal analysis of urease from Helicobacter-pylori. Infection and Immunity, 58(4), 992-998. https://doi. org/10.1128/IAI.58.4.992-998.1990

Joshi, C. S. \& Priya, E. S. (2007). Betaglucuronidase inhibitory effect of phenolic constituents from phyllanthus amarus. Pharmaceutical Biology, 45(5), 363-365. https : / / doi .org / $10.1080 /$ 13880200701214706

Karak, S., Nag, G. \& De, B. (2017). Metabolic profile and beta-glucuronidase inhibitory property of three species of swertia. Revista Brasileira de FarmacognosiaBrazilian Journal of Pharmacognosy, 27(1), 105-111. https:// doi .org / 10 . 1016/j.bjp.2016.07.007

Kaskoniene, V., Maruska, A., Kornysova, O., Charczun, N., Ligor, M. \& Buszewski, B. (2009). Quantitative and qualitative determination of phenolic compounds in honey. Chemine Technologija, 52(3), 74-80.

Khan, R. U., Naz, S. \& Abudabos, A. M. (2017). Towards a better understanding of the therapeutic applications and corresponding mechanisms of action of honey. Environmental Science and Pollution Research, 24(36, SI), 2775527766. https://doi.org/10.1007/s11356017-0567-0

Kim, D., Jin, Y., Park, J. \& Kobashi, K. (1994). Silymarin and its components are inhibitors of beta-glucuronidase. Biological and Pharmaceutical Bulletin, 17(3), 443-445. https: / / doi.org / 10. $1248 /$ bpb. 17.443

Kuhns, L. G., Mahawar, M., Sharp, J. S., Benoit, S. \& Maier, R. J. (2013). Role of helicobacter pylori methionine sulfoxide reductase in urease maturation. Biochemical Journal, 450(1), 141-148. https:// doi.org/10.1042/BJ20121434 
Lateef, M., Iqbal, L., Fatima, N., Siddiqui, K., Afza, N., Zia-ul-Haq, M. \& Ahmad, M. (2012). Evaluation of antioxidant and urease inhibition activities of roots of glycyrrhiza glabra. Pakistan Journal of Pharmaceutical Sciences, 25(1), 99-102.

Lin, Y. T., Kwon, Y. I., Labbe, R. G. \& Shetty, K. (2005). Inhibition of helicobacter pylori and associated urease by oregano and cranberry phytochemical synergies. Applied and Environmental Microbiology, 71(12), 8558-8564. https: / / doi. org / 10.1128/AEM .71.12.8558-8564. 2005

Marghitas, L. A., Dezmirean, D., Moise, A., Bobis, O., Laslo, L. \& Bogdanov, S. (2009). Physico-chemical and bioactive properties of different floral origin honeys from romania. Food Chemistry, 112(4), 863-867. https:// doi.org / 10. 1016/j.foodchem.2008.06.055

Martínez-Flórez, S., González-Gallego, J., Culebras, J. M. \& Tuñón, M. J. (2002). Los flavonoides: Propiedades y acciones antioxidantes. Nutrición hospitalaria, 17(6), 271-278.

Meda, A., Lamien, C. E., Romito, M., Millogo, J. \& Nacoulma, O. G. (2005). Determination of the total phenolic, flavonoid and proline contents in burkina fasan honey, as well as their radical scavenging activity. Food Chemistry, 91(3), 571577. https : / / doi . org / 10.1016/j . foodchem.2004.10.006

Mouhoubi-Tafinine, Z., Ouchemoukh, S. \& Tamendjari, A. (2016). Antioxydant activity of some algerian honey and propolis [2nd Mediterranean Symposium on Medicinal and Aromatic Plants (MESMAP), Antalya, TURKEY, APR 22-25, 2015]. Industrial Crops and Products, 88(SI), 85-90. https:// doi . org/10.1016/j.indcrop.2016.02.033

Niki, E. (2011). Antioxidant capacity: Which capacity and how to assess it? Journal of Berry Research, 1(4), 169-176.

Pimentel-Gonzalez, D. J., Jimenez-Alvarado, R., Hernandez-Fuentes, A. D., Figueira, A. C., Suarez-Vargas, A. \& CamposMontiel, R. G. (2016). Potentiation of bioactive compounds and antioxidant activity in artisanal honeys using specific heat treatments. Journal of Food Biochemistry, 40(1), 47-52. https:// doi. org/10.1111/jfbc. 12186

Pontis, J. A., Alves da Costa, L. A. M., Reis da Silva, S. J. \& Flach, A. (2014). Color, phenolic and flavonoid content, and antioxidant activity of honey from roraima, brazil. Food Science and Technology, 34(1), 69-73. https://doi.org/ 10.1590/S0101-20612014005000015

Quintero-Lira, A., Angeles Santos, A., AguirreAlvarez, G., Reyes-Munguia, A., Almaraz-Buendia, I. \& Campos-Montiel, R. G. (2017). Effects of liquefying crystallized honey by ultrasound on crystal size, 5-hydroxymethylfurfural, colour, phenolic compounds and antioxidant activity. European Food Research and Technology, 243(4), 619-626. https : //doi.org/10.1007/s00217-016-2775-0

Rao, P. V., Krishnan, K. T., Salleh, N. \& Gan, S. H. (2016). Biological and therapeutic effects of honey produced by honey bees and stingless bees: A comparative review. Revista Brasileira de Farmacognosia- Brazilian Journal of Pharmacognosy, 26(5), 657-664. https: //doi.org/10.1016/j.bjp.2016.01.012

Re, R., Pellegrini, N., Proteggente, A., Pannala, A., Yang, M. \& Rice-Evans, C. (1999). Antioxidant activity applying an improved abts radical cation decolorization assay. Free Radical Biology and Medicine, 26 (9-10), 1231-1237. https:// doi.org/10.1016/S0891-5849(98)00315-3

Ruiz-Navajas, Y., Viuda-Martos, M., FernandezLopez, J., Manuel Zaldivar-Cruz, J., Kuri, V. \& Angel Perez-Alvarez, J. (2011). Antioxidant activity of artisanal honey from tabasco, mexico. International Journal of Food Properties, 14 (2), 459-470. https : / / doi .org / 10 . 1080 / 10942910903249480

Shim, S. B., Kim, N. J. \& Kim, D. H. (2000). Beta-glucuronidase inhibitory activity and hepatoprotective effect of 18 betaglycyrrhetinic acid from the rhizomes of glycyrrhiza uralensis. Planta Medica, 
66 (1), 40-43. https://doi.org/10.1055/ s-2000-11109

Singleton, V. L., Orthofer, R. \& LamuelaRaventós, R. M. [14] analysis of total phenols and other oxidation substrates and antioxidants by means of folinciocalteu reagent. In: Methods in enzymology. Vol. 299. Elsevier, 1999, pp. $152-178$.

Sodre, G. D. S., Marchini, L. C., De Carvalho, C. A. L. \& Moreti, A. C. D. C. C. (2007). Pollen analysis in honey samples from the two main producing regions in the brazilian northeast. Anais da Academia Brasileira de Ciencias, $79(3), 381-388$.

Yao, L. H., Datta, N., Tomas-Barberan, F. A., Ferreres, F., Martos, I. \& Singanusong, R. (2003). Flavonoids, phenolic acids and abscisic acid in australian and new zealand leptospermum honeys. Food Chemistry, 81(2), 159-168. https://doi. org/10.1016/S0308-8146(02)00388-6 